\title{
Lipid Peroxidation Induced by the Reaction of Cytochrome $c$ with Hydrogen Peroxide
}

\author{
Jung Hoon Kang \\ Department of Genetic Engineering, Cheongju University, Cheongju 360-764, Korea. E-mail: jhkang@cju.ac.kr \\ Received February 1, 2006
}

\begin{abstract}
Lipid peroxidation induced by the reaction of cytochrome $c$ with $\mathrm{H}_{2} \mathrm{O}_{2}$ was investigated. When linoleic acid micelles or phosphatidyl choline liposomes were incubated with cytochrome $c$ and $\mathrm{H}_{2} \mathrm{O}_{2}$, lipid peroxidation was increased in cytochrome $c$ and $\mathrm{H}_{2} \mathrm{O}_{2}$ concentrations-dependent manner. Radical scavengers, azide, formate and ethanol prevented lipid peroxidation induced by the cytochrome $c / \mathrm{H}_{2} \mathrm{O}_{2}$ system. Iron specific chelator, desferoxamine also prevented the cytochrome $c / \mathrm{H}_{2} \mathrm{O}_{2}$ system-mediated lipid peroxidation. These results suggest that lipid peroxidation may be induced by the cytochrome $c / \mathrm{H}_{2} \mathrm{O}_{2}$ system via the generation of free radicals. Carnosine, homocarnosine and anserine are present in the muscle and brain of many animals and human. Previous studies show that these compounds have an antioxidant function. In the present study, carnosine, homocarnosine and anserine significantly prevented the cytochrome $c / \mathrm{H}_{2} \mathrm{O}_{2}$ system-mediated lipid peroxidation. Carnosine and related compounds also inhibited the free radical-generating activity of cytochrome $c$. The results suggest that carnosine, homocarnosine and anserine may prevent lipid peroxidation induced by the cytochrome $c / \mathrm{H}_{2} \mathrm{O}_{2}$ system through a free radical scavenging.
\end{abstract}

Key Words : Cytochrome $c$, Lipid peroxidation, Free radical, Carnosine

\section{Introduction}

Cytochrome $c$ is an electron transport protein and it catalyses peroxidase-like reactions in vitro. ${ }^{1}$ It catalyses several reactions such as hydroxylation and aromatic oxidation and shows peroxidase activity by oxidation of various electron donors such as 2-keto-4-thiomethyl butyric acid, and 4-aminoantipyrine. ${ }^{2}$ Recently, it has been reported that this protein was closely related with two other biological processes, apoptosis and oxidative stress. ${ }^{3,4}$ Apoptosis, also called programmed cell death, is key to development and is linked to human diseases, including cancer and neurodegeneration. ${ }^{5,6}$ The cellular damage associated with oxidative stress has also been related with several diseases, such as Parkinson's disease (PD). ${ }^{7}$ One consequence of the long exposure to oxidants is the oxidation of lipids (called lipid peroxidation) in cell membranes and lipoproteins. It is becoming increasingly evident that peroxidative damage to low-density lipoprotein plays a key role in the etiology of atherosclerosis. ${ }^{8,9}$ Lipid peroxidation may also contribute to other human diseases, such as certain types of cancer, rheumatoid arthritis, and myocardial reoxygenation injury as well as to the degenerative processes associated with aging. ${ }^{10}$ Although the ability of the cytochrome $c$ and $\mathrm{H}_{2} \mathrm{O}_{2}$ system to oxidize organic molecules is well known, a mechanism for the lipid peroxidation by this system has not been reported.

In this study, the cytochrome $c$ and $\mathrm{H}_{2} \mathrm{O}_{2}$ system-mediated lipid peroxidation was studied. The present results suggest that the lipid peroxidation induced by cytochrome $c$ and $\mathrm{H}_{2} \mathrm{O}_{2}$ is due to the oxidative damage resulting from free radicals generated by a combination of the peroxidase activity of cytochrome $c$ and the Fenton reaction of free iron released from oxidatively damaged cytochrome $c$.

\section{Materials and Methods}

Materials. Desferoxamine (DFX), linoleic acid, soybean phosphatidylcholine, thiobarbituric acid and trichloroacetic acid were purchased from Sigma Chemical Co. (St. Louis, MO, U.S.A.). Chelex 100 resin (sodium form) was obtained from Bio-Rad (Hercules, CA, U.S.A.).

Preparation of phospholipid liposomes and fatty acid micelles. The phospholipid liposomes were prepared according to the method previously described. ${ }^{11}$ Soybean phosphatidylcholine dissolved in chloroform-methanol was placed in a round bottom flask, and chloroform-methanol was removed using a rotary vacuum evaporator to obtain a thin lipid film on the flask wall. An appropriate amount of $10 \mathrm{mM}$ potassium phosphate ( $\mathrm{pH} 7.4$ ) was added, and the mixture was shaken vigorously to yield a milky suspension. The suspension was then sonicated 3 times at 30 watts for 20 $\mathrm{s}$ at $4{ }^{\circ} \mathrm{C}$ to obtain unilamellar liposomes. The linoleic acid stock solution of $10 \mathrm{mg} / \mathrm{mL}$ was prepared in ethanol, and stored at $-20{ }^{\circ} \mathrm{C}$ under nitrogen. Immediately prior to use, an aliquot of the stock solution was dried with nitrogen, diluted with $10 \mathrm{mM}$ potassium phosphate ( $\mathrm{pH} 7.4$ ) to a concentration of $10 \mathrm{mg}$ fatty acid $/ \mathrm{mL}$, and then sonicated 3 times at 30 watts for $5 \mathrm{~s}$ at $4{ }^{\circ} \mathrm{C}$ to form fatty acid micelles.

Assay for lipid peroxidation. As an index of lipid peroxidation, thiobarbituric acid-reactive substance (TBARS) was determined by a modification of the method previously described. ${ }^{12}$ Linoleic acid micelles $(1 \mathrm{mg} / \mathrm{mL})$ or phosphatidylcholine liposomes $(1 \mathrm{mg} / \mathrm{mL})$ were incubated with different concentrations of cytochrome $c$ and $\mathrm{H}_{2} \mathrm{O}_{2}$ in 10 $\mathrm{mM}$ potassium phosphate buffer $(\mathrm{pH} 7.4)$ in a total volume of $100 \mu \mathrm{L}$. The incubations were performed at $37{ }^{\circ} \mathrm{C}$ for various periods. The reaction was stopped by the addition of $200 \mu \mathrm{L}$ of $6 \%$ trichloroacetic acid. The reaction mixture was 
mixed with phosphate buffered saline $(200 \mu \mathrm{L})$, and $1 \%$ thiobarbituric acid $(200 \mu \mathrm{L})$, and boiled at $100{ }^{\circ} \mathrm{C}$ for 15 min. After the samples were cooled and centrifuged at $15,000 \mathrm{rpm}$ for $10 \mathrm{~min}$. The differential absorbance of the supernatant fractions at $532 \mathrm{~nm}$ was measured spectrophotometrically. The amount of TBARS was determined by comparison to a standard curve constructed using malondialdehyde (MDA). All solutions were treated with Chelex 100 resin to remove any traces of transition metal ions.

Measurement of free radical. The free radical-generating activity of cytochrome $c$ was measured by using a chromogen, 2,2'-azinobis-(2-ethylbenzthiazoline-6-sulfonate) (ABTS) ${ }^{13}$ ABTS is water-soluble and has a strong absorption at $340 \mathrm{~nm}$ with a molar extinction coefficient $\varepsilon_{340}$ of $3.66 \times 10^{4} \mathrm{M}^{-1} \mathrm{~cm}^{-1} .{ }^{14}$ On oxidation, ABTS forms a stable blue-green product presumed to be the cation radical, $\mathrm{ABTS}^{+}$is conveniently followed at $\lambda_{\max }$ at $415 \mathrm{~nm}\left(\varepsilon_{415}=\right.$ $\left.3.6 \times 10^{4} \mathrm{M}^{-1} \mathrm{~cm}^{-1}\right){ }^{15}$ The assay mixture contained $10 \mathrm{mM}$ potassium phosphate buffer ( $\mathrm{pH}$ 7.4) and $50 \mu \mathrm{M}$ ABTS and $0.3 \mathrm{mM}$ hydrogen peroxide and $5 \mu \mathrm{M}$ protein in a total volume of $1 \mathrm{~mL}$. The reaction was initiated by addition of hydrogen peroxide and the increase in absorbance at $415 \mathrm{~nm}$ was measured by using a UV/Vis spectrophotometer (Shimazu 1601).

Replicates. Unless otherwise indicated, each result described in this paper is representative of at least three separate experiments

\section{Results and Discussion}

Figure 1 shows the peroxidation of fatty acid and phospholipid induced by the cytochrome $c / \mathrm{H}_{2} \mathrm{O}_{2}$ system. The peroxidation of linoleic acid micelles did not occur after the incubation with $1.5 \mu \mathrm{M}$ cytochrome $c$ or $150 \mu \mathrm{M} \mathrm{H}_{2} \mathrm{O}_{2}$ alone. However, when the fatty acid micelles were incubated in a mixture of cytochrome $c$ and $\mathrm{H}_{2} \mathrm{O}_{2}$, lipid peroxidation was increased for $120 \mathrm{~min}$ in a time-dependent manner (Fig. 1A). A similar result was obtained when the phosphatidylcholine liposomes were incubated in the cytochrome $c / \mathrm{H}_{2} \mathrm{O}_{2}$ system (Fig. 1B). These results indicate that both cytochrome $c$ and $\mathrm{H}_{2} \mathrm{O}_{2}$ were required for lipid peroxidation. The time course of the reaction for the generation of the peroxidized lipid products, measured with thiobarbituric acidreactive substance (TBARS), in linoleic acid micelles was more rapid and pronounced than in the phosphatidylcholine liposomes. This may be because the liberated linoleic acid has a relatively greater propensity for free radical attack than the variety of polyunsaturated fatty acids present in the phospholipid bilayer of the biomembranes. The effects of cytochrome $c$ and $\mathrm{H}_{2} \mathrm{O}_{2}$ concentrations on lipid peroxidation were studied. The peroxidation of both the linoleic acid micelles and phosphatidylcholine liposomes was increased by concentrations up to $3 \mu \mathrm{M}$ cytochrome $c$ (Fig. 2A) and $300 \mu \mathrm{M} \mathrm{H}_{2} \mathrm{O}_{2}$ (Fig. 2B), respectively. The results show that lipid peroxidation induced by the cytochrome $c / \mathrm{H}_{2} \mathrm{O}_{2}$ system is dependent on the concentrations of cytochrome $c$ and $\mathrm{H}_{2} \mathrm{O}_{2}$.
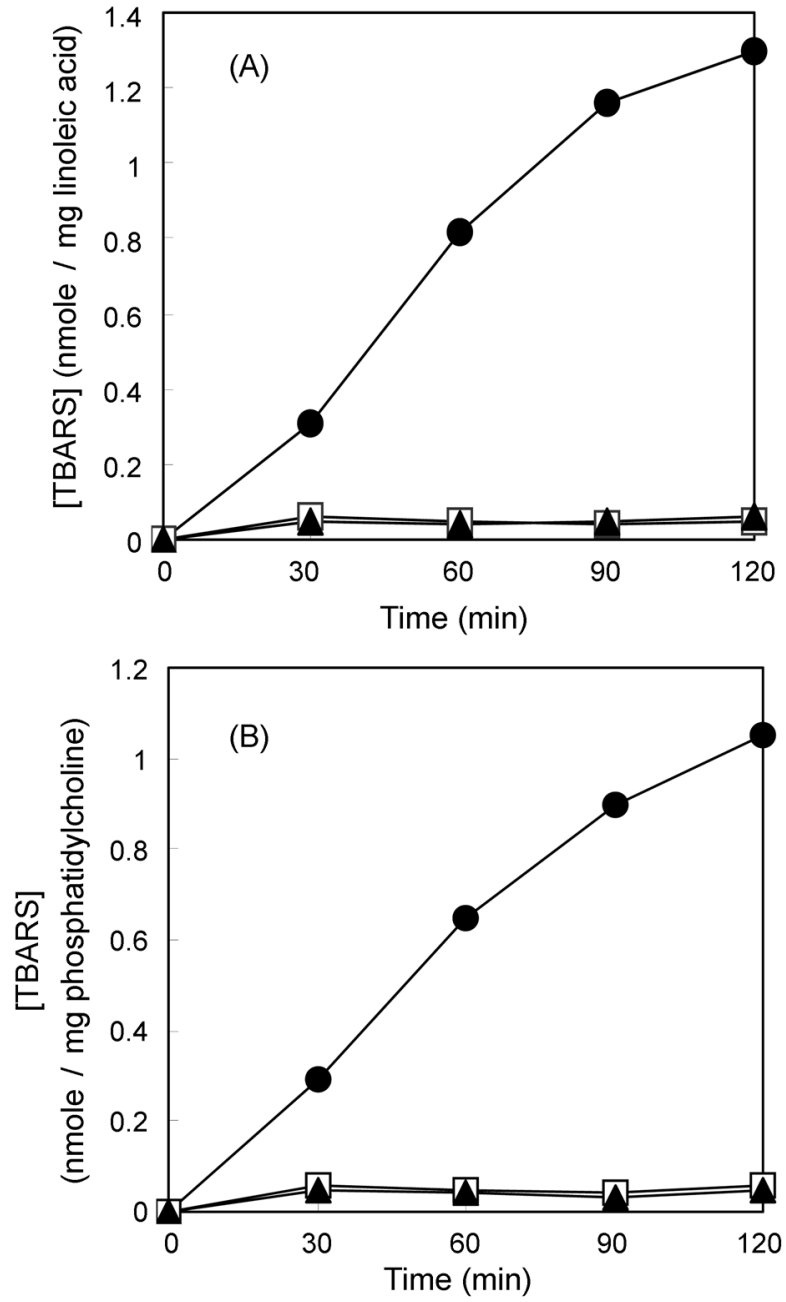

Figure 1. Lipid peroxidation induced by the incubation with cytochrome $c$ and $\mathrm{H}_{2} \mathrm{O}_{2}$. Linoleic acid micelles (A) or phosphatidylcholine liposome (B) was incubated at $37^{\circ} \mathrm{C}$ for various incubation periods with the following; $1.5 \mu \mathrm{M}$ cytochrome $c$ alone $(\square) ; 150$ $\mu \mathrm{M} \mathrm{H} \mathrm{H}_{2} \mathrm{O}_{2}$ alone ( $\Delta$ ); $1.5 \mu \mathrm{M}$ cytochrome $c$ plus $150 \mu \mathrm{M} \mathrm{H}_{2} \mathrm{O}_{2}$ (๑).

Previous reports showed that free radicals were generated in the reaction of cytochrome $c$ with $\mathrm{H}_{2} \mathrm{O}_{2}$, and that free radical formation was linear with respect to the concentrations of cytochrome $c$ and $\mathrm{H}_{2} \mathrm{O}_{2}{ }^{13}$ The participation of free radical in lipid peroxidation induced by the cytochrome $c / \mathrm{H}_{2} \mathrm{O}_{2}$ system was studied by examining the protective effects of the free radical scavengers such as azide, formate, and ethanol. When the linoleic acid micelles or the phosphatidylcholine liposomes were incubated with cytochrome $c$ and $\mathrm{H}_{2} \mathrm{O}_{2}$ in the presence of radical scavengers, all scavengers significantly prevented lipid peroxidation (Table 1). These results suggest that free radicals may participate in the mechanism of lipid peroxidation induced by the cytochrome $c / \mathrm{H}_{2} \mathrm{O}_{2}$ system.

Trace metal such as iron and copper, which are variously present in biological systems, may interact with reactive oxygen species, to damage macromolecules. ${ }^{16-19}$ The cleavage of the metalloproteins by oxidative damage may lead to 

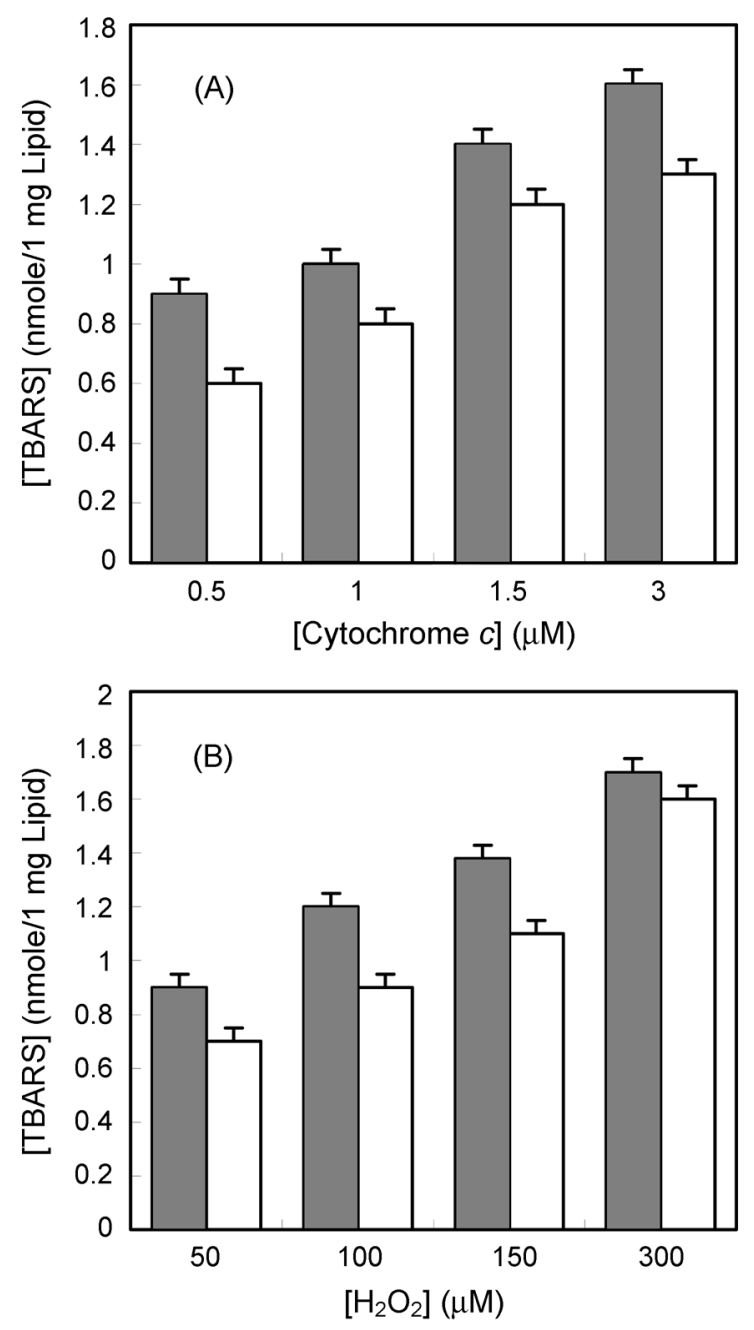

Figure 2. Effects of cytochrome $c$ and $\mathrm{H}_{2} \mathrm{O}_{2}$ concerntrations on the lipid peroxidation. (A) Linoleic acid micelles ( $\square$ ) or phosphatidylcholine liposome $(\square)$ was incubated with 0.5-3 $\mu \mathrm{M}$ cytochrome $c$ and $150 \mu \mathrm{M} \mathrm{H}_{2} \mathrm{O}_{2}$ at $37^{\circ} \mathrm{C}$ for $2 \mathrm{~h}$. (B) Linoleic acid micelles $(\square)$ or phosphatidylcholine liposome $(\square)$ was incubated with $1.5 \mu \mathrm{M}$ cytochrome $c$ and $50-300 \mu \mathrm{M} \mathrm{H}_{2} \mathrm{O}_{2}$.

increases in the levels of metal ions in some biological cell. ${ }^{20}$ Previous reports showed that a metal chelator inhibited the peroxidase activity of cytochrome $c .^{21}$ The participation of iron ions in the cytochrome $c / \mathrm{H}_{2} \mathrm{O}_{2}$-mediated lipid peroxidation was investigated by an examination of the protective effects of the iron chelator DFX. The results showed that DFX prevented the peroxidation of both the linoleic acid micelles and phosphatidylcholine liposomes induced by the cytochrome $c / \mathrm{H}_{2} \mathrm{O}_{2}$ system (Fig. 3). It has been reported that iron ions released from the reaction of cytochrome $c$ with $\mathrm{H}_{2} \mathrm{O}_{2}$. This is likely due to the peroxidase activity of cytochrome $c$. Since iron ions could stimulate Fenton reaction to produce hydroxyl radical, lipid peroxidation is mediated in the cytochrome $c / \mathrm{H}_{2} \mathrm{O}_{2}$ system via the generation of hydroxyl radicals.

The previous reports showed that the interaction between ferricytochrome $c$ and hydrogen peroxide would initially from an oxoferryl derivative of hemoprotein. ${ }^{13}$ Oxoferryl
Table 1. Effect of radical scavengers on lipid peroxidation induced by the cytochrome $c$ and hydrogen peroxide system

\begin{tabular}{lccrcr}
\hline \multirow{2}{*}{ Additive } & $\begin{array}{c}\text { Concen- } \\
\text { tration }\end{array}$ & \multicolumn{2}{c}{$\begin{array}{c}\text { Linoleic acid } \\
\text { Amount of TBARS }\end{array}$} & & \multicolumn{2}{c}{$\begin{array}{c}\text { Phosphatidylcholine } \\
\text { (nmole/mg Lipid) (\%) }\end{array}$} \\
\hline None & & (nmole/mg Lipid) & $(\%)$ \\
Azide & $10 \mathrm{mM}$ & $0.48 \pm 0.05$ & 33 & $0.36 \pm 0.06$ & 30 \\
& $50 \mathrm{mM}$ & $0.02 \pm 0.05$ & 1 & $0.04 \pm 0.06$ & 4 \\
Formate & $10 \mathrm{mM}$ & $0.68 \pm 0.02$ & 47 & $0.52 \pm 0.03$ & 45 \\
& $50 \mathrm{mM}$ & $0.04 \pm 0.03$ & 3 & $0.05 \pm 0.03$ & 4 \\
Ethanol & $10 \mathrm{mM}$ & $0.87 \pm 0.05$ & 60 & $0.82 \pm 0.06$ & 70 \\
& $50 \mathrm{mM}$ & $0.26 \pm 0.07$ & 18 & $0.31 \pm 0.03$ & 26 \\
\hline
\end{tabular}

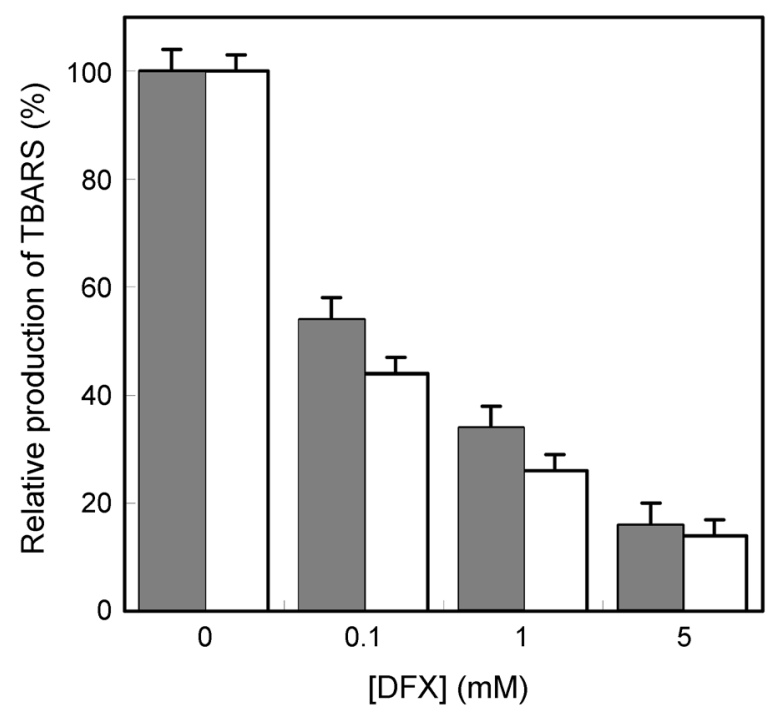

Figure 3. Effect of DFX on the lipid peroxidation induced by the cytochrome $c$ and $\mathrm{H}_{2} \mathrm{O}_{2}$. Linoleic acid micelles $(\square)$ or phosphatidylcholine liposomes $(\square)$ was incubated with $1.5 \mu \mathrm{M}$ cytochrome $c$ and $150 \mu \mathrm{M} \mathrm{H}_{2} \mathrm{O}_{2}$ at $37^{\circ} \mathrm{C}$ for $2 \mathrm{~h}$. in the absence of DFX or in the presence of various concentrations of DFX.

cytochrome $c$, similar to compound I of peroxidases, is assumed to contain two oxidizing equivalents, one in the form of oxoferryl heme $\left(\mathrm{Fe}^{\mathrm{IV}}=\mathrm{O}\right)$, and another as the porphyrin $\pi$ radical. ${ }^{13}$ Recent study reported that melatonin oxidation by cytochrome $c$ would be mediated through the family of oxoferryl heme species of cytochrome $c .^{22}$ Hydrogen peroxide could induce a short-lived cytochrome $c$ derived tyrosyl radical as detected by the electron spin resonance spin-trapping technique. ${ }^{23}$ Therefore, the present results suggest that lipid peroxidation can be mediated by an oxoferryl heme species or the protein tyrosyl radical as well as a Fenton-type reaction producing hydroxyl radical. Evidence that the iron chelator DFX and hydroxyl radical scavengers could not completely prevent the reaction activity of cytochrome $c$ supports this mechanism.

Carnosine and related compounds, homocarnosine, anserine are present in the muscle and brain tissues of human and other vertebrates in relatively high concentrations (1-20 $\mathrm{mM}) .^{24,25}$ These compounds have been shown to be very efficient antioxidant molecules. ${ }^{26}$ It was found that carnosine 
(A)

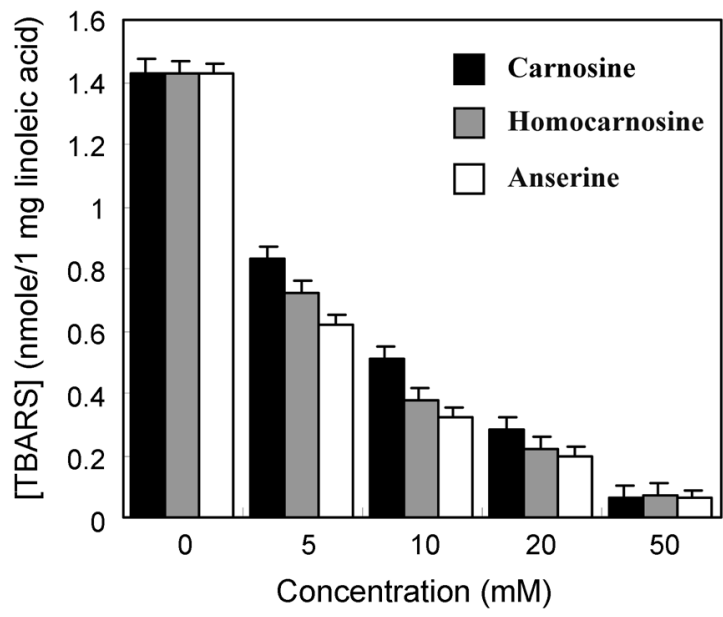

(B)

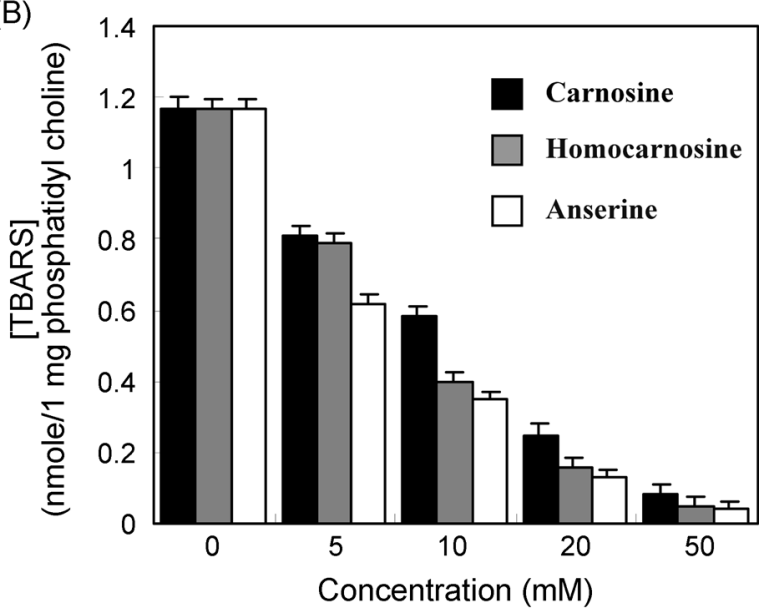

Figure 4. Effects of carnosine and related compound on the lipid peroxidation in the cytochrome $c$ and $\mathrm{H}_{2} \mathrm{O}_{2}$ system. Linoleic acid micelles (A) or phosphatidylcholine liposome (B) was incubated with $1.5 \mu \mathrm{M}$ cytochrome $c$ and $150 \mu \mathrm{M} \mathrm{H}_{2} \mathrm{O}_{2}$ at $37^{\circ} \mathrm{C}$ for $2 \mathrm{~h}$ in the presence of various concentrations of carnosine ( $\boldsymbol{\square})$, homocarnosine $(\square)$ and anserine $(\square)$.

and related compounds significantly inhibited the lipid peroxidation induced by the cytochrome $c / \mathrm{H}_{2} \mathrm{O}_{2}$ system (Fig. 4). It has been reported that carnosine and related compounds quench $50-95 \%$ of hydroxyl radicals produced in the Fenton reaction. ${ }^{27}$ The effects of carnosine and related compounds on the generation of free radical by the cytochrome $c / \mathrm{H}_{2} \mathrm{O}_{2}$ system were examined. The free radicalgenerating activity of cytochrome $c$ was measured by using a chromogen, 2,2'-azinobis-(2-ethylbenzthiazoline-6-sulfonate) (ABTS). ${ }^{13}$ ABTS is water-soluble and has a strong absorption at $340 \mathrm{~nm}$ with a molar extinction coefficient $\varepsilon_{340}$ of $3.66 \times 10^{4} \mathrm{M}^{-1} \mathrm{~cm}^{-1} \cdot{ }^{21}$ Attack of $\cdot \mathrm{OH}$ on ABTS forms a stable blue-green product presumed to be the cation radical, $\mathrm{ABTS}^{+}$is conveniently followed at $\lambda_{\text {max }}$ at $415 \mathrm{~nm} .{ }^{14}$ This can be used to detect $\cdot \mathrm{OH}$ production, although it is unclear whether or not some other reactive oxygen species can also form $\mathrm{ABTS}^{+}$. When cytochrome $c$ was incubated with $\mathrm{H}_{2} \mathrm{O}_{2}$ in the presence of carnosine, homocarnosine and anserine at
Table 2. Effect of carnosine and related compounds on the formation of $\mathrm{ABTS}^{+\cdot}$ by cytochrome $c / \mathrm{H}_{2} \mathrm{O}_{2}$ system

\begin{tabular}{lrcc}
\hline \multirow{2}{*}{ Additive } & \multirow{2}{*}{ Concentration } & \multicolumn{2}{c}{ ABTS $^{+\cdot}$} \\
\cline { 3 - 4 } & & $\mu$ mole/min & $\%$ of control \\
\hline None & & $0.597 \pm 0.06$ & 100 \\
Carnosine & $0.1 \mathrm{mM}$ & $0.292 \pm 0.05$ & 49 \\
& $1 \mathrm{mM}$ & $0.124 \pm 0.04$ & 21 \\
Homocarnosine & $0.1 \mathrm{mM}$ & $0.306 \pm 0.08$ & 51 \\
& $1 \mathrm{mM}$ & $0.167 \pm 0.06$ & 28 \\
Anserine & $0.1 \mathrm{mM}$ & $0.313 \pm 0.06$ & 52 \\
& $1 \mathrm{mM}$ & $0.235 \pm 0.05$ & 39 \\
\hline
\end{tabular}

$37^{\circ} \mathrm{C}$, all compounds significantly inhibited the free radicalgenerating activity of cytochrome $c$ (Table 2). These compounds might be able to bind $\mathrm{Cu}^{2+}$ and prevent some $\mathrm{Cu}^{2+}$ dependent radical reaction. However, it has not been found to chelate iron in a manner that reduces its prooxidant activity. ${ }^{24}$ Thus, the ability of carnosine to prevent the cytochrome $c / \mathrm{H}_{2} \mathrm{O}_{2}$-mediated lipid peroxidation is likely due to free radical scavenging activity.

Lipid peroxidation has been hypothesized to play a critical role in a number of serious human diseases, such as cancer, atherosclerosis, rheumatoid arthritis and myocardial reoxygenation injury as well as in the degenerative processes associated with aging. ${ }^{28,29}$ It has been reported that at least $0.1 \mathrm{mM} \mathrm{H}_{2} \mathrm{O}_{2} / \mathrm{min}$ can be produced continuously under physiological conditions and at a much higher rates under adverse conditions such as hyperoxia or ischemia and reperfusion. ${ }^{30,31}$ Hence, under these abnormal conditions, the oxidative damage of lipid induced by the cytochrome $c$ system may be operative in vivo.

In conclusion, the results presented here suggest that lipid peroxidation can be induced by the reaction of cytochrome $c$ with $\mathrm{H}_{2} \mathrm{O}_{2}$, involving free radical generation. It can be assumed that carnosine, homocarnosine and anserine may protect the lipid peroxidation the cytochrome $c / \mathrm{H}_{2} \mathrm{O}_{2}$ system through the mechanism of free radical scavenging.

\section{References}

1. Vazquez-Duhalt, R. J. Mol. Catal. B Enzym. 1999, 7, 241.

2. Harel, S.; Kanner, J. J. Free Radic. Res. Commun. 1988, 5, 21.

3. Li, P.; Nijhawan, D.; Budihardjo, I.; Srinvasula, S. M.; Ahmad, M.; Alnermri, E. S.; Wang, X. Cell 1997, 91, 627.

4. Hashimoto, M.; Takeda, A.; Hsu, L. J.; Takenouchi, T.; Masliah, E. J. Biol. Chem. 1999, 274, 28849.

5. Green, D. R.; Evan, G. I. Cancer Cell 2002, 1, 19.

6. Shimizu, S.; Narita, N.; Tsujimoto, Y. Nature 1999, 399, 483.

7. Wang, X.; Pielak, G. J. Biochemistry 1999, 38, 16876.

8. Steinberg, D.; Parthasarathy, S.; Carew, T. E.; Khoo, J. C.; Witztum, J. L. New Engl. J. Med. 1989, 320, 915.

9. Schwartz, C. J.; Valente, A. J.; Sprague, E. A.; Kelley, J. L.; Nerem, R. M. Clin. Cardiol. 1991, 14, 1.

10. Halliwell, B.; Gutteridge, J. M. C. Arch. Biochem. Biophys. 1989, 246, 501.

11. Motoyama, T.; Miki, M.; Mino, M.; Takahashi, M.; Niki, E. Arch. Biochem. Biophys. 1989, 270, 655.

12. Schuh, J.; Fairclough, G. F. Jr.; Haschemeyer, R. H. Proc. Natl. Acad. Sci. USA 1978, 75, 3173. 
13. Radi, R.; Thomson, R.; Rubbo, L.; Prodanov, E. Arch. Biochem. Biophys. 1991, 288, 112.

14. Rush, J. D.; Koppenol, W. H. J. Am. Chem. Soc. 1988, 110, 4957.

15. Childs, R. E.; Bardsley, W. G. Biochem. J. 1975, 145, 93.

16. Goldstein, S.; Czapski, G. J. Am. Chem. Soc. 1986, 108, 2244.

17. Sagripanti, J. L.; Swicord, M. L.; Davis, C. C. Radiat. Res. 1987, $110,219$.

18. Imlay, J. A.; Chin, S. M.; Linn, S. Science 1988, 240, 640.

19. Sagripanti, L.; Kraemer, K. H. J. Biol. Chem. 1989, 264, 1729.

20. Kang, J. H.; Kim, S. M. Mol. Cells 1997, 7, 553.

21. Kim, N. H.; Jeong, M. S.; Choi, S. Y.; Knag, J. H. Bull. Korean Chem. Soc. 2004, 25, 1889.

22. Semak, I.; Naumova, M.; Korik, E.; Terekhovich, V.; Wortsman, J.; Slominski, A. Biochemistry 2005, 44, 9300.

23. Chen, Y.-R.; Chen, C.-L.; Chen, W.; Zweier, J. L.; Augusto, O.; Radi, R.; Mason, R. P. J. Biol. Chem. 2004, 279, 18054.
24. Kohen, R.; Yamamoto, Y.; Cundy, K. C.; Ames, B. N. Proc. Natl. Acad. Sci. U.S.A. 1988, 85, 3175.

25. O'Dowd, J. J.; Robins, D. J.; Miller, D. J. Biochem. Biophys. Acta 1988, 967, 241.

26. Auroma, O. I.; Laughton, M. J.; Halliwell, B. Biochem. J. 1989, $264,863$.

27. Chan, W. K. M.; Decker, E. A.; Lee, J. B.; Butterfield, D. A. J. Agric. Food Chem. 1994, 42, 1407.

28. Steinberg, D.; Parthasarathy, S.; Carew, T. E.; Khoo, J. C.; Witztum, J. L. New Engl. J. Med. 1989, 320, 915.

29. Schwartz, C. J.; Valente, A. J.; Sprague, E. A.; Kelley, J. L.; Nerem, R. M. Clin. Cardiol. 1991, 14, 1.

30. Boritton, R. S.; Oshino, N.; Chance, B. Biochem. J. 1972, 128, 617.

31. Britton, R. S.; Bacon, B. R.; Recknagel, R. O. Chem. Phys. Lipids 1987, 45, 207. 